\title{
Disruption of neuromedin B receptor gene results in dysregulation of the pituitary-thyroid axis
}

\author{
K J Oliveira, T M Ortiga-Carvalho, A Cabanelas, M A L C Veiga, K Aoki', \\ H Ohki-Hamazaki ${ }^{2}$, K Wada ${ }^{1}$, E Wada ${ }^{1}$ and C C Pazos-Moura \\ Laboratório de Endocrinologia Molecular, Instituto de Biofísica Carlos Chagas Filho, Universidade Federal do Rio de Janeiro, Rio de Janeiro, 21949-900, Brazil \\ ${ }^{1}$ Department of Degenerative Neurological Diseases, National Institute of Neuroscience, National Center of Neurology and Psychiatry, Tokyo, Japan \\ ${ }^{2}$ Laboratory of Molecular Neuroscience, School of Biomedical Science and Medical Research Institute, Tokyo Medical and Dental University, Tokyo, Japan
}

(Requests for offprints should be addressed to C C Pazos-Moura; Email: cpazosm @ biof.ufrj.br)

\begin{abstract}
The level of thyrotropin (TSH) secretion is determined by the balance of TSH-releasing hormone (TRH) and thyroid hormones. However, neuromedin B (NB), a bombesin-like peptide, highly concentrated in the pituitary, has been postulated to be a tonic inhibitor of TSH secretion. We studied the pituitary-thyroid axis in adult male mice lacking NB receptor (NBR-KO) and their wild-type (WT) littermates. At basal state, NBR-KO mice presented serum TSH slightly higher than WT $(18 \%, P<0.05)$, normal intra-pituitary TSH content, and no significant changes in $\alpha$ and $\beta$ TSH mRNA levels. Serum thyroxine was normal but serum triiodothyronine (T3) was reduced by $24 \%(P<0.01)$ in NBR-KO mice. Pituitaries of NBR-KO mice exhibited no alteration in prolactin mRNA expression but type I and II deiodinase mRNA levels were reduced by 53 and $42 \%$ respectively $(P<0.05)$, while TRH receptor mRNA levels were importantly increased $(78 \%, P<0.05)$. The TSH-releasing effect of TRH was significantly higher in NBR-KO than in WT mice (7.1and 4.0 -fold respectively), but, while WT mice presented a $27 \%$ increase in serum T3 $(P<0.05)$ after TRH, NBR-KO mice showed no change in serum T3 after TRH. NBR-KO mice did not respond to exogenous NB, while WT showed a $30 \%$ reduction in serum TSH. No compensatory changes in mRNA expression of NB or other bombesin-related peptides and receptors (gastrin-releasing peptide (GRP), GRP-receptor and bombesin receptor subtype-3) were found in the pituitary of NBR-KO mice. Therefore, the data suggest that NB receptor pathways are importantly involved in thyrotroph gene regulation and function, leading to a state where TSH release is facilitated especially in response to $\mathrm{TRH}$, but probably with a less-bioactive TSH. Therefore, the study highlights the important role of NB as a physiological regulator of pituitary-thyroid axis function and gene expression.
\end{abstract}

Journal of Molecular Endocrinology (2006) 36, 73-80

\section{Introduction}

The level of thyrotropin (TSH) secretion is determined mainly by the balance of the stimulatory effect of hypothalamic TSH-releasing hormone (TRH) and the strong inhibition exerted by thyroid hormones. However, other modulators of TSH secretion have been described, and among those, neuromedin B (NB). NB is a mammalian peptide structurally and functionally related to the amphibian peptide bombesin (Minamino et al. 1983). Bombesin-like peptides elicit several biological effects when injected into mammals, acting through three related types of receptors (Battey et al. 1991, Wada et al. 1991, Weber et al. 1998); one of these binds preferentially NB (Wada et al. 1991). NB receptor (NB-R) is present in the pituitary gland (Houben et al. 1993), although it has a wide distribution, predominantly in the central nervous system (Wada et al. 1991) and gastrointestinal cells (Von Schrenck et al. 1989). NB-R is a G-protein-coupled receptor (Wada et al. 1991) and NB binding results in activation of multiple signaling pathways, depending on the cell studied (Wang et al. 1992, Lach et al. 1995, Moody et al. 1995). NB-R signal transduction pathways had not been studied at the pituitary level.

Bombesin-like peptides have been shown to decrease TSH release in rodents and humans (Pontiroli \& Scarpignato 1986, Pazos-Moura et al. 2003); however, only for NB is there compelling evidence for a physiological role. NB reduced serum TSH when administered into normal and hypothyroid rats (Rettori et al. 1989, 1992) and the blockade of endogenous NB employing a highly specific antiserum against the peptide injected into the third cerebral ventricle induced a rise in serum TSH in both euthyroid and hyperthyroid rats (Rettori et al. 1992). NB acts directly at the pituitary, since isolated rat pituitaries released less TSH in the presence of the peptide (Rettori et al. 1989, Tajima et al. 1989). In addition, NB is abundantly expressed in human and rat pituitaries (Jones et al. 1992, Houben et al. 1993). In fact, in the rat, pituitary is the tissue that 
exhibits the higher concentration of NB, predominantly found in thyrotrophs (Steel et al. 1988). The relative abundance of the peptide mRNA in pituitary indicates that NB is locally produced, and when its action was blocked by incubating normal or hyperthyroid glands with a specific antiserum, TSH release increased (Rettori et al. 1992), suggesting that pituitary NB exerts a tonic inhibitory effect on TSH secretion, acting as an autocrine/paracrine regulator. Conditions with increased TSH release, such as hypothyroidism and acute cold exposure, are associated with decreased pituitary NB expression (Jones et al. 1992, OrtigaCarvalho et al. 2003), while suppressed TSH secretion induced by hyperthyroidism, and also observed in experimental fasting and diabetes mellitus, was associated with increased pituitary NB (Jones et al. 1992, Ortiga-Carvalho et al. 1997). Moreover, TRH acute administration rapidly decreased the pituitary content of the peptide and its mRNA (Ortiga-Carvalho et al. 2003), while acute injection of thyroid hormones increased NB expression (Ortiga-Carvalho et al. 1996).

Taken together, our previous work proposed that NB is a constitutive inhibitor of TSH release, acting mainly as an autocrine/paracrine factor, and that the control of its pituitary expression by TSH secretagogues or TSH release inhibitors may serve to modulate the final action of these hormones. However, the focus of those was on acute NB effects on TSH release, and here we studied in an animal model the long-term consequences of the disruption of the NB-R gene on pituitary-thyroid axis function and pituitary gene expression. NB-R knockout (NBR-KO) mice have been previously described (Ohki-Hamazaki et al. 1999). They presented a reduced response to the central hypothermic effect of exogenously administered NB (Ohki-Hamazaki et al. 1999), and behavioral changes, such as decreased marble-burying behavior and difficulties in learning and memory related to stress situations (Yamada et al. 2002a, 2003) as well as alterations in maternal behavior induced by stress (Yamada et al. 2002b). Here we report for the first time that NBR-KO mice present alterations in pituitary gene expression, with functional consequences for the thyrotroph-thyroid axis.

\section{Materials and methods}

\section{Experimental animals}

All experiments were conducted in adult male mice at 3-4 months old, homozygous for the deletion in NB-R (NBR-KO) and their wild-type (WT) littermates. Heterozygous NB-R + / - mice generated as described by Ohki-Hamazaki et al. (1999), were interbred to generate litters containing homozygous NB-R - / and NB-R +/+ progeny. Mice studied were from
F16 to F23. To confirm the genotype of the mice, genomic DNA was obtained from tail samples and analyzed by PCR using specific primers as described previously (Ohki-Hamazaki et al. 1999).

Animals were maintained under a controlled temperature $\left(22 \pm 1{ }^{\circ} \mathrm{C}\right)$ and a $12 \mathrm{~h}$ alternating darkness and artificial light cycle (lights on at $0700 \mathrm{~h}$ ) and fed laboratory chow and water freely. All animals were killed in the morning between 0930 and $1130 \mathrm{~h}$. In all experiments body weight (BW) of NBR-KO mice was similar to WT (25-28 g).

All procedures were performed in accordance with the Fund for the Replacement of Animals in Medical Experiments Guide for the care and use of laboratory animals and were approved by our Institutional Committee on Animal Care and Use.

\section{Basal state of pituitary gene expression and pituitary-thyroid axis function}

In order to evaluate the consequences of the deletion of NB-R on the pituitary-thyroid axis at steady state, NBR-KO and WT mice were taken from cages and immediately killed by asphyxia with $\mathrm{CO}_{2}$ followed by decapitation. Trunk blood samples were centrifuged and serum was stored at $-20^{\circ} \mathrm{C}$ for triiodothyronine (T3), thyroxine (T4) and TSH determinations by specific RIAs. To determine TSH content, each pituitary was homogenized in $200 \mu \mathrm{l}$ phosphosaline buffer, $\mathrm{pH} 7 \cdot 6$, and supernatants stored at $-20{ }^{\circ} \mathrm{C}$ until assayed at a final dilution of 1:2000. Another set of pituitaries was immediately frozen in liquid nitrogen until processed to evaluate mRNA levels of $\alpha$ - and $\beta$-subunits of TSH, TRH-receptor (TRH-R), prolactin, 5'-deiodinase type I (DI) and 5'-deiodinase type II (DII) by fluorescence real-time RT-PGR.

\section{TRH stimulation of TSH release}

NBR-KO and WT mice received a single s.c. injection of saline (control group) or TRH (Sigma) at doses of 0.05 or $0.5 \mu \mathrm{g} / \mathrm{kg}$ BW and were killed $30 \mathrm{~min}$ after injection. Mice were killed by asphyxia with $\mathrm{CO}_{2}$ followed by decapitation and trunk blood was collected and serum stored at $-20{ }^{\circ} \mathrm{C}$ for TSH and T3 determinations.

\section{NB effect on TSH release}

NBR-KO and WT mice received a single s.c. injection of $50 \mu \mathrm{g}(44 \cdot 16 \mathrm{nmol}) \mathrm{NB}$ (Sigma) per animal, $30 \mathrm{~min}$ before killing, or the same volume of saline (control group). Mice were killed by asphyxia with $\mathrm{CO}_{2}$ followed by decapitation and trunk blood was collected and serum stored at $-20{ }^{\circ} \mathrm{C}$ for TSH determinations. 


\section{Expression of bombesin-related peptides and receptors in pituitary gland}

In order to investigate whether the lack of NB-R could induce compensatory changes in pituitary expression of bombesin-like peptides and their related receptors, pituitaries from NBR-KO and WT mice were immediately frozen in liquid nitrogen until processed to evaluate mRNA levels of NB, gastrin-releasing peptide (GRP), GRP-receptor (GRP-R) and bombesin receptor subtype-3 (BRS-3) by fluorescence real-time RT-PCR.

\section{Hormone measurements}

Serum TSH was measured in $100 \mu \mathrm{l}$ serum samples in duplicate determinations by a specific mouse TSH RIA using a mouse TSH/LH reference preparation (AFP51718 MP), a mouse TSH antiserum (AFP98991), and rat TSH antigen for radioiodination (NIDDKrTSH-I-9, AFP-11542B). All reagents were obtained from Dr A F Parlow at the National Hormone and Peptide Program (Harbor University of California at Los Angeles Medical Center, Torrance, CA, USA). Samples or standards were incubated in phosphosaline buffer, $\mathrm{pH} 7 \cdot 6$, containing $1 \%(\mathrm{w} / \mathrm{v}) \mathrm{BSA}$, for $21 \mathrm{~h}$ at room temperature with the antiserum at a final dilution of 1:150 000 and ${ }^{125}$ I-TSH (10 000 c.p.m./tube). At the end of the incubation period, a second antibody at a final dilution of 1:100 was added (goat anti-guinea pig $\mathrm{IgG}$; Antibodies Incorporated, Davis, CA, USA) and after $3 \mathrm{~h}$ at room temperature the tubes were centrifuged $\left(4{ }^{\circ} \mathrm{C}\right)$ at $1600 \boldsymbol{g}$ for $30 \mathrm{~min}$ and radioactivity was measured in the precipitate. TSH was labeled with ${ }^{125} \mathrm{I}$ in our laboratory by the chloramine-T method (Hunter \& Greenwood 1962). Minimum assay detection was $30 \mathrm{ng} / \mathrm{ml}$. The intra-assay variations were $<7 \%$. All samples from each experiment were measured within the same assay.

Serum total T3 and T4 concentrations were measured by a coated tube RIA from ICN Pharmaceuticals (Costa Mesa, CA, USA) using 100 and $25 \mu \mathrm{l}$ of serum respectively. The sensitivity of the assay is $0.76 \mu \mathrm{g} / \mathrm{dl}$ for $\mathrm{T} 4$ and $6.7 \mathrm{ng} / \mathrm{dl}$ for $\mathrm{T} 3$. The intra-assay variation was $4 \cdot 7 \%$ for $\mathrm{T} 4$ and $2 \cdot 6 \%$ for $\mathrm{T} 3$.

\section{Fluorescence real-time RT-PCR}

Analysis of TSH $a$-and $\beta$-subunits, TRH-R, prolactin, DI and DII mRNAs

Pituitary total RNA was purified using TRIZOL (Invitrogen, Carlsbad, CA, USA) and single-stranded cDNA was synthesized from $2 \mu \mathrm{g}$ pituitary total RNA using Superscript II (Invitrogen). Real-time RT-PCR analyses were performed in fluorescence temperature cyclers (MyiQ single color Real-time PCR Detection System; Bio-Rad), according to recommendations of the manufacturer. Briefly, after initial denaturation at $50{ }^{\circ} \mathrm{C}$ for $2 \mathrm{~min}$ and $95^{\circ} \mathrm{C}$ for $10 \mathrm{~min}$, reactions were cycled 40 times using the following conditions: $95^{\circ} \mathrm{C}$ for $15 \mathrm{~s}$, $60{ }^{\circ} \mathrm{C}$ for $30 \mathrm{~s}$ and $72{ }^{\circ} \mathrm{C}$ for 30s. SYBR Green I fluorescence was detected at the end of each cycle to monitor the amount of PCR product formed during that cycle. The sequences of the forward and reverse primers were respectively: 5'-GTG TAT GGG CTG TTG CTT CTC C-3' and 5'-GGA CTC CGT ATG ATT CTC CAC TCT G-3' for TSH $\alpha$-subunit; 5'-TCT CGG CGT CCT CGT CTC CGT GGT T-3' and 5'-AGT TGG TTG TGA CAG CGT CGT G-3' for TSH $\beta$-subunit; $5^{\prime}$-AGG CAG CTC TAC GGG GC-3' and 5'-CGC TTG TAG CAG ATG CTG CG-3' for DI; 5'-CAT TGT GGT CAA GCA GGT GGG-3' and 5'-GAC GTG CAC CAC ACT GGA ATT-3' for DII; 5'-GGA GTG ACG ATG AGG ATG AA- $3^{\prime}$ and 5'-AGA TTG GCA GAG GCT GAA CA-3' for prolactin; 5'-CTG GAT CTC AAC ATC AGG ACG TAC-3' and 5'-GGA AGA TAC TGT GGT GTT GAA GCA-3' for TRH-R; 5'-CGG CTA CGA CAT GGA AGG AA- ${ }^{\prime}$ and $5^{\prime}$-GCT GGA ATT ACG GGG GCT-3' for 18S; 5'-GCA AGG ATG GCA AGG ATT GA-3' and 5'-AGG AAT TCT GGC TGG ATA GG-3' for cyclophilin.

\section{Analysis of bombesin-related peptides and receptor mRNAs}

Pituitary total RNA was purified using Rneasy kit (Qiagen) and the single-stranded cDNA was synthesized from $1 \mu \mathrm{g}$ total RNA, using a high-capacity cDNA archive kit (Applied Biosystems). Real-time RT-PCR analyses were performed in an Applied Biosystems 7700 Sequence Detection System, according to recommendations of the manufacturer. PCR conditions were: $95{ }^{\circ} \mathrm{C}$ for $10 \mathrm{~min}$, followed by 40 cycles at $95^{\circ} \mathrm{C}$ for $15 \mathrm{~s}$ and $60{ }^{\circ} \mathrm{C}$ for $1 \mathrm{~min}$. SYBR Green I fluorescence was detected at the end of each cycle to monitor the amount of PCR product formed during that cycle. The sequences of the forward and reverse primers were respectively: 5'-AAT TGG CTG CAA ACT GAT CGG- $3^{\prime}$ and $5^{\prime}$-TGG CGG TAG AAT GGG TTT GT-3' for GRP-R; 5'-AAA GCA CGC TGA ACA TAC CGA-3' and 5'-CAA CAA GCA GAG TGG GAA CA-3' for BRS-3; 5'-ATG AAT CGG CGT CGG TGT ATG- $3^{\prime}$ and $5^{\prime}$-AGG AGG TGG AGG AAA TGG CTT-3' for GRP; 5'-CGG TCA GTT CAT GGG CAA G-3' and 5'-GAG GTT TCT TTC GCA GGA GGA-3' for NB. $\beta$-Actin and glyceraldehyde-3-phosphate dehydrogenase (GAPDH) primers were as described previously (Aoki et al. 2002).

The threshold cycle of each gene was determined as the PCR cycle at which an increase in fluorescence was observed above the baseline signal in an amplification plot. The normalized expression level of target $(\Delta \mathrm{C} t)$ was 
calculated as the difference in threshold cycles for target and reference (18S, cyclophilin, $\beta$-actin or GAPDH). Relative mRNA levels were determined by comparing the PCR cycle threshold $(\mathrm{Ct})$ between groups. The purity of the PCR products was checked by analyzing the melting curves. Each sample was measured in duplicate and each experiment was repeated at least three times.

\section{Statistical analyses}

Data are expressed as means \pm S.E.M. A two-tailed unpaired $t$-test was employed for assessment of significance of all data except for serum TSH and T3 in the TRH experiment, which was analyzed by one-way ANOVA followed by the Student-Newman-Keuls multiple comparisons test (GraphPad Prism, GraphPad Software, Inc., San Diego, CA, USA). Serum TSH was analyzed only after logarithmic transformation. Differences were considered to be significant at $P \leq 0 \cdot 05$.

\section{Results}

\section{Basal state of pituitary gene expression and pituitary-thyroid axis function}

As depicted in Fig. 1A and B, TSH $\beta$ - and $\alpha$-subunit mRNA levels of NBR-KO mice were not significantly different from WT, although the $\beta$-subunit mRNA showed a trend toward reduction. The intra-pituitary TSH pool of NBR-KO mice was normal, since mice of both genotypes had similar pituitary TSH content (Fig. 1C). Serum TSH of NBR-KO mice was slightly higher than that of WT (approximately 18\%, Fig. 1D, $P<0 \cdot 05)$. There was no difference between NBR-KO mice and WT littermates in serum T4 (Fig. 1E). However, serum T3 was reduced by $24 \%$ in NBR-KO mice (Fig. 1E, $P<0 \cdot 01$ ).

As shown in Fig. 2A, NBR-KO mice exhibited a 78\% increase in the expression of TRH-R mRNA $(P<0 \cdot 05)$. Prolactin mRNA was similar between genotypes (Fig. 2B). However, both DI and DII mRNA levels were decreased in NBR-KO mice, by 53 and $42 \%$ respectively (Fig. $2 \mathrm{C}$ and $\mathrm{D}, P<0 \cdot 05$ ).

\section{TRH stimulation of TSH release}

NBR-KO mice showed a markedly enhanced TSH response to acute administration of $\mathrm{TRH}$, as shown in Fig. 3A. The lower TRH dose $(0 \cdot 05 \mu \mathrm{g} / \mathrm{kg} \mathrm{BW})$ induced a $4 \cdot 3$-fold increase in serum TSH of NBR-KO mice $(P<0 \cdot 001$ vs saline control group), while the increment was of $2 \cdot 9$-fold in WT $(P<0 \cdot 001$ vs. saline control group). The higher TRH dose $(0 \cdot 5 \mu \mathrm{g} / \mathrm{kg} \mathrm{BW})$ resulted in a more pronounced difference between the response
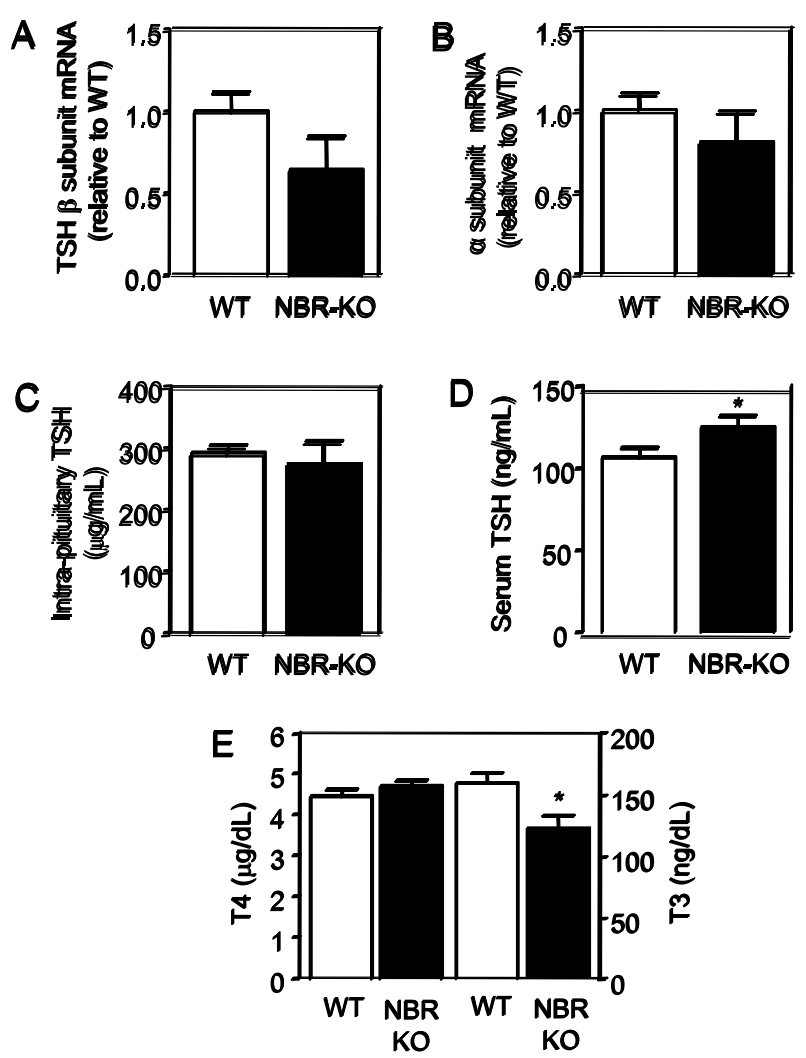

Figure 1 Pituitary-thyroid axis in NB-R knockout mice (NBR-KO) and wild-type littermates (WT) at basal state. (A, B) Pituitary TSH $\beta$ - and $\alpha$-subunit mRNA analyzed by fluorescence real-time RT-PCR. Data were normalized for each mRNA level relative to WT animals ( $n=8-12$ per group). (C) Pituitary TSH content ( $n=7-10$ per group). (D) Serum TSH concentration ( $n=28-34$ per group). (E) Serum T4 and T3 concentrations ( $n=16-22$ per group). ${ }^{*} P<0.05$ vs WT group. Data are means \pm S.E.M.

of NBR-KO and WT mice $(7 \cdot 1-$ and $4 \cdot 0$-fold increase in serum TSH respectively, $P<0.001$ vs saline control group). At both TRH doses, serum TSH concentrations reached in NBR-KO mice were significantly higher when compared with WT groups $(P<0.01$ at lower dose; $P<0.001$ at higher dose).

As shown in Fig. 3B, WT mice exhibited a $27 \%$ increase in serum T3 after TRH administration $(P<0 \cdot 05)$. However, despite higher serum TSH, NBR-KO mice showed no increment in serum T3 after TRH. Therefore, the ratio of serum TSH/T3 after TRH was $8.6 \pm 0.53$ in NBR-KO mice, while it was $4 \cdot 5 \pm 0.48$ in WT mice (Fig. $3 \mathrm{C}, P<0 \cdot 001$ ).

\section{Effect of NB administration on serum TSH}

WT mice, 30 min after receiving a single s.c. injection of NB, showed a $30 \%$ lower serum TSH as compared with the saline-injected WT group $(P<0 \cdot 001)$. This percentage of decrease in serum TSH induced by NB is similar 

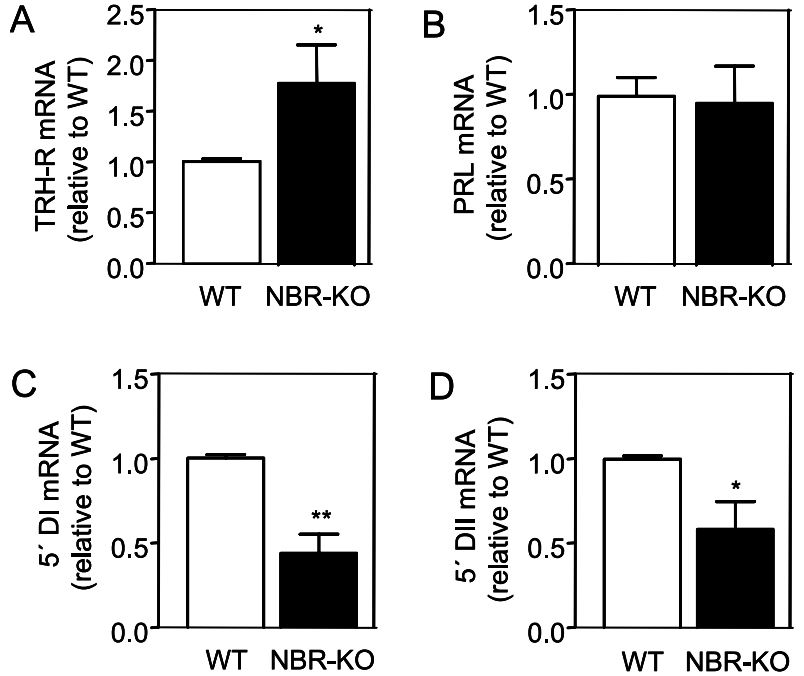

Figure 2 Pituitary gene expression in NB-R knockout mice (NBR-KO) and wild-type littermates (WT) at the basal state. (A) TRH-R. (B) Prolactin (PRL). (C, D) Pituitary 5'-deiodinase type I (DI) and type II (DII). mRNA levels were analyzed by fluorescence real-time RT-PCR. Data were normalized for each mRNA level relative to WT animals. $n=8-12$ per group. Data are means \pm S.E.M. ${ }^{*} P<0.05$ and ${ }^{* *} P<0.001$ vs WT group.

to that previously described in rats (Rettori et al. 1989). Conversely, NBR-KO mice showed no significant response to the peptide injection (Fig. 4).

These results showed that in mice lacking NB-R, serum TSH concentration was not significantly affected by NB injection.

\section{Expression of bombesin-related peptides and receptors in pituitary gland}

NBR-KO mice showed no alterations in pituitary mRNA levels of NB and GRP as well as GRP-R and BRS-3, as illustrated in Fig. 5. $\Delta \mathrm{Ct}$ values of each gene were similar in mice lacking NB-R and WT mice (GRP-R: $\quad \mathrm{WT}=17 \cdot 8 \pm 0 \cdot 45, \quad \mathrm{NBR}-\mathrm{KO}=18 \cdot 1 \pm 0 \cdot 24$; BRS-3: $\quad \mathrm{WT}=16 \cdot 6 \pm 0 \cdot 28, \quad \mathrm{NBR}-\mathrm{KO}=17 \cdot 7 \pm 0 \cdot 52$; GRP: $\mathrm{WT}=13 \cdot 6 \pm 0 \cdot 38, \mathrm{NBR}-\mathrm{KO}=13 \cdot 1 \pm 0 \cdot 35 ; \mathrm{NB}$ : $\mathrm{WT}=6 \cdot 3 \pm 0 \cdot 12, \quad \mathrm{NBR}-\mathrm{KO}=6 \cdot 2 \pm 0 \cdot 12$ ). Therefore, deletion of NB-R did not elicit compensatory changes in the expression levels of bombesin-related receptors and peptides, including $\mathrm{NB}$, the receptor's preferential ligand.

\section{Discussion}

Previous studies have proposed a physiological role for $\mathrm{NB}$ as a negative modulator of TSH release, acting mainly as an autocrine/paracrine inhibitor, whose pituitary expression is under the control of TSH
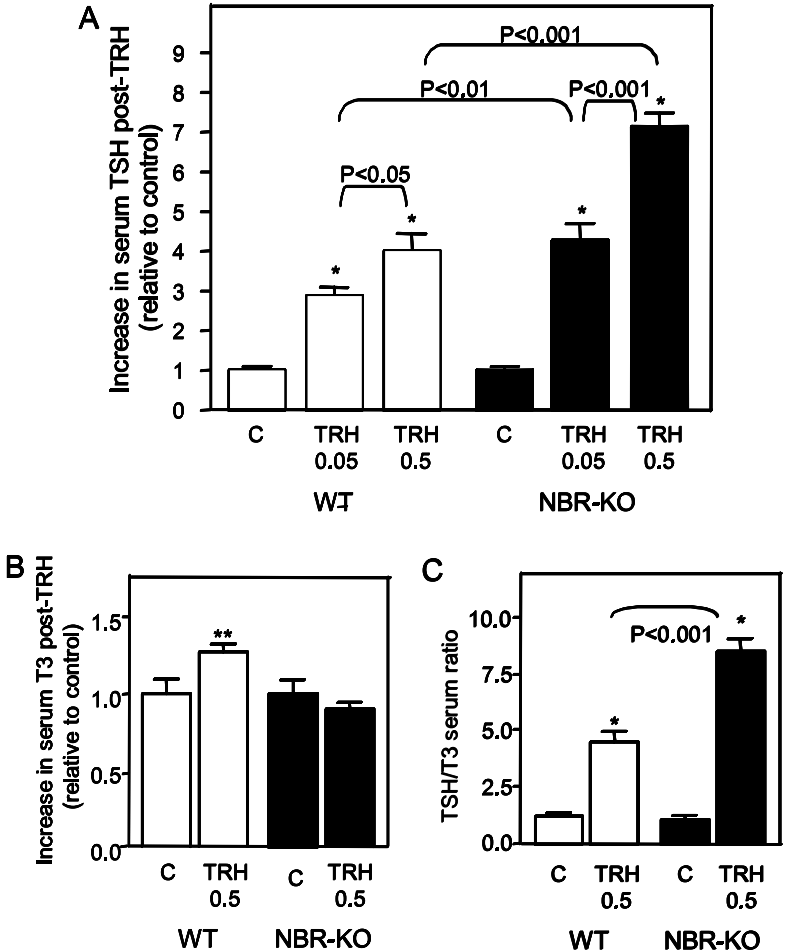

Figure 3 Pituitary-thyroid axis response to TRH acute administration in NB-R knockout mice (NBR-KO) and wild-type littermates (WT). Mice received a single s.c. injection of TRH $(0.05$ or $0.5 \mu \mathrm{g} / \mathrm{kg} \mathrm{BW}) 30 \mathrm{~min}$ before killing. One group of each genotype remained as control $(C)$ and received saline. Values are means \pm S.E.M. of the increase in serum TSH $(A)$, serum T3 $(B)$ and TSH/T3 serum ratio $(C)$ induced by TRH relative to control groups of the corresponding genotype. $n=8-10$ per group. ${ }^{\star} P<0.001$ vs control group, ${ }^{\star \star} P<0.05$ vs control group.

secretagogues and TSH-releasing inhibitors. However, those studies focused on acute effects of the peptide or the antiserum, and therefore allowed drawing of conclusions related to the release of stored TSH, leading to the suggestion that $\mathrm{NB}$ acts to inhibit the TSH secretory mechanism. Here, studying mice lacking NB-R we were able to demonstrate the long-term role of NB in the regulation of pituitary-thyroid axis hormonal secretion and gene regulation.

At basal state, NBR-KO mice showed a slight higher serum TSH, without significant changes in TSH $\beta$-subunit mRNA levels or in intracellular TSH storage. More importantly, NBR-KO mice showed an exaggerated TSH response to acute administration of TRH. Together, the data suggest that NBR-KO mice have a higher rate of TSH release, which is consistent with the lack of NB action as an inhibitor of the TSH secretory mechanism. The facilitated TSH-releasing action of TRH in NBR-KO mice is also justified by the higher expression of TRH-R mRNA. This is in agreement with 
WT NBR-KO

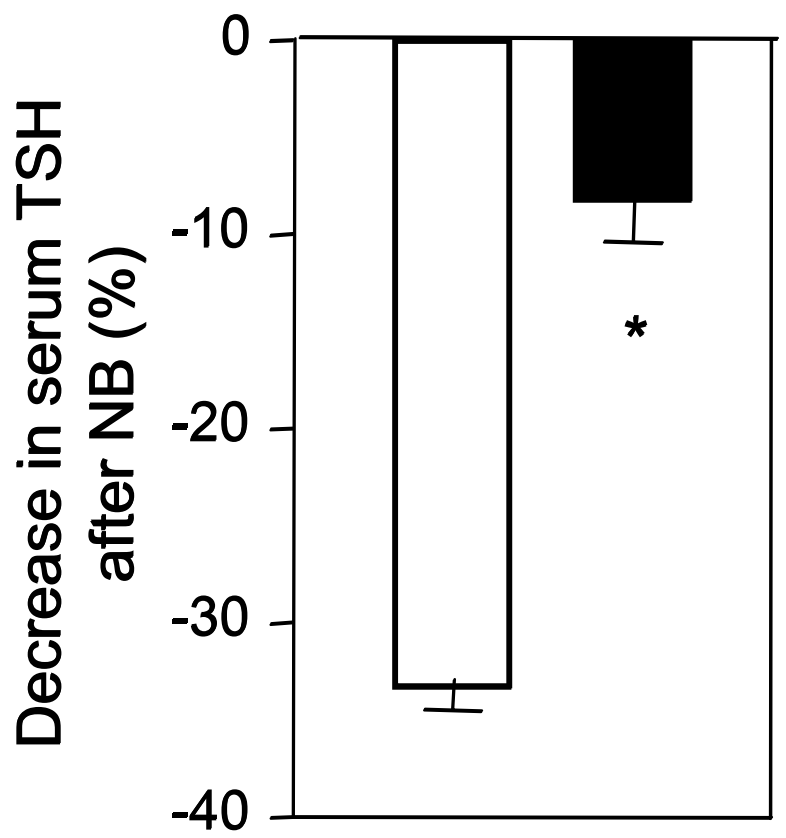

Figure 4 Serum TSH decrease in response to a single injection of neuromedin B (NB) in NB-R knockout mice (NBR-KO) and wild-type littermates (WT). Mice received a single s.c. injection of NB (50 $\mathrm{\mu g}$ per animal) or saline $30 \mathrm{~min}$ before killing. Values represent the percentage decrease relative to saline-treated groups of the corresponding genotype. $n=8-9$ per group. ${ }^{*} P<0.001$ vs WT NB-treated group. Data are means \pm S.E.M.

previous reports showing the ability of NB to reduce TRH-induced TSH release (Pazos-Moura et al. 1996) and may justify why TRH has a rapid and profound inhibitory effect on pituitary NB expression, as demonstrated previously in rats (Ortiga-Carvalho et al.

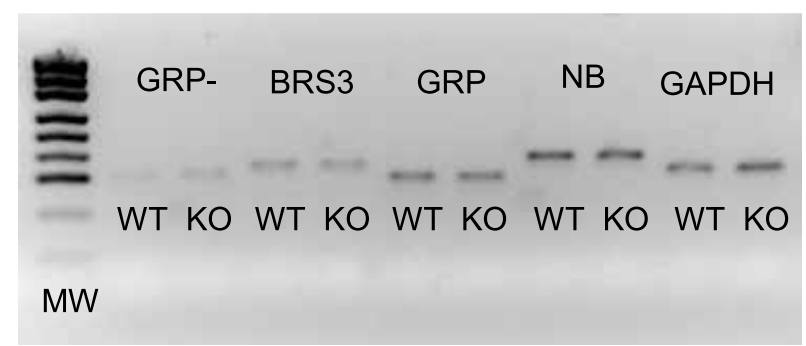

Figure 5 Pituitary mRNA expression of bombesin-related receptors: gastrin-releasing peptide receptor (GRP-R), bombesin receptor subtype-3 (BRS-3), and peptides: GRP and neuromedin $B(N B)$ in NB-R knockout mice (KO) and wild-type littermates (WT) at basal state. The mRNA expression was evaluated by fluorescence real-time RT-PCR. The figure illustrates a representative agarose gel visualization obtained with reaction samples collected when their amplification curves were linear. $\mathrm{MW}=$ molecular weight (pUC19 DNA/Mspl). The range of standard was 34-501 bp.
2003). Therefore, the data suggest that NB has an important antagonistic effect on TRH action on the release of stored $\mathrm{TSH}$, and at least one possible mechanism is by regulating, directly or indirectly, TRH-R mRNA expression. However, there was not an overall increment in TRH action in thyrotrophs, since TSH $\alpha$ - and $\beta$-subunit mRNA levels were not increased as expected, since TRH is a well-known stimulator of expression of both mRNAs. Therefore, NBR-KO mice present other alterations in thyrotroph function.

Although TSH secretion seems to be facilitated in NBR-KO mice, it is likely that the hormone has decreased biological activity, since serum T3 was reduced, and more importantly, NBR-KO did not show the expected rise in serum T3 after TRH, even though their TSH release was $3 \cdot 4$-fold higher than that of WT. This in vivo indirect evidence should be confirmed by in vitro bioassay, although they are highly suggestive of a less-bioactive TSH. The serum T3 response to TRH was reduced in some patients with central hypothyroidism, whose basal TSH was slightly elevated and less bioactive (Faglia et al. 1983). Mice lacking TRH had slightly higher serum TSH, low serum T3 and T4, and showed diminished T3 response to endogenous TSH after TRH stimulation, which was considered as evidence of reduction in TSH bioactivity (Yamada et al. 1997). This is in agreement with the role of TRH in regulation of TSH biological activity (Persani 1998). Low serum T3, in the presence of normal T4 and normal or slightly reduced serum TSH, is present in initial stages of starvation or mild illnesses, the so-called non-thyroidal illness syndrome (De Groot 1999), which has a multifactorial cause, but exhibit in common the suppression of TRH gene expression (Lechan \& Fekete 2004). Although there is no previous study on NB effects on TRH, NB-R had been localized in the paraventricular nucleus (Wada et al. 1992), and it is possible that NBR-KO mice have some degree of TRH deficiency, although mild, since serum T4 is normal. However, another possibility is that NB itself may be a direct pituitary regulator of TSH bioactivity, which remains to be tested in specific in vitro studies.

Another original finding of this study is the previously unsuspected involvement of $\mathrm{NB}$ in the regulation of DI and DII mRNA expression in the pituitary gland. The mechanism for reduction of both deiodinase mRNAs as well as the specific pituitary cells involved cannot be elucidated by the present study, and these alterations may represent direct or indirect effects of NB. T3 is a major regulator of deiodinase mRNAs, and up-regulates DI and down-regulates DII mRNA (Maia et al. 1995, Kim et al. 1998). Therefore, the lower serum T3 of NBR-KO mice could be associated with reduced pituitary DI mRNA, although it is uncertain since T4 was normal. However, the decrease in DII mRNA must have another cause, not related to T3. A previous report 
has shown that TRH, dexamethasone and 8-Br-cAMP cause modest increases in DII mRNA levels in pituitary tumor cells (Kim et al. 1998). However, it remains to be studied if NBR-KO mice have any alterations in those factors or if $\mathrm{NB}$ is a direct regulator of mRNA expression of these enzymes. Independently of the underlying mechanisms, the reduction of pituitary DI and especially DII mRNA, leading to lower pituitary T3 generation, can potentially contribute to increased TSH release in response to TRH, since $\mathrm{T} 3$ is able to down-regulate TRH-R (Schomburg \& Bauer 1995). The fact that pituitary deiodinase mRNAs are reduced raises the question of whether these enzymes are changed in other tissues and if this would contribute to reduced serum T3. However, thyroid axis abnormalities of NBR-KO mice strongly suggest that their primary defect is at the central level.

NBR-KO mice lost the ability to respond to NB by decreasing serum TSH, which indicates that the acute action of NB on TSH release is being mediated via NB-preferring receptors. Therefore, it is reasonable to assume that the phenotype observed in NBR-KO mice resulted from the lack of action of endogenous NB. This is further supported by the absence of a compensatory increase in expression of pituitary NB or other bombesin-like receptors, which have a much lower affinity for NB, and therefore, could not mediate NB actions at normal levels of the peptide.

In conclusion, this study reveals that NB-R pathways are involved, directly or indirectly, in regulation of pituitary genes, as the lack of NB-R resulted in increased TRH-R mRNA and decreased DI and DII mRNAs in association with increased TSH release, especially in response to TRH. Even so, serum T3 at the basal state and after TRH stimulation was decreased, suggesting a reduction in TSH biological activity. Therefore, the study highlights the important role of NB not only as an inhibitor of TSH release, but also in the regulation of pituitary gene expression, with functional consequences for thyrotroph-thyroid axis function.

\section{Acknowledgements}

We would like to thank Dr F Wondisford for helping in the initial set up of the pituitary gene mRNA study by real-time PCR. This work was supported by CNPq, FAPERJ. There is no conflict of interest that would prejudice its impartiality.

\section{References}

Aoki K, Sun YJ, Aoki S, Wada K \& Wada E 2002 Cloning, expression, and mapping of a gene that is up regulated in adipose tissue of mice deficient in bombesin receptor subtype-3. Biochemical and Biophysical Research Communications 290 1282-1288.
Battey JF, Way JM, Corjay MH, Shapira H, Kusano K, Harkins R, Wu JM, Slattery T, Mann E \& Feldman RI 1991 Molecular cloning of the bombesin/gastrin-releasing peptide receptor from Swiss 3T3 cells. PNAS 88 395-399.

De Groot LJ 1999 Dangerous dogmas in medicine: the nonthyroidal illness syndrome. Fournal of Clinical Endocrinology and Metabolism $\mathbf{8 4}$ 151-164

Faglia G, Beck-Peccoz, Ballabio M \& Nava C 1983 Excess of $\beta$-subunit of thyrotropin (TSH) in patients with idiopathic central hypothyroidism due to the secretion of TSH with reduced biological activity. Fournal of Clinical Endocrinology and Metabolism $\mathbf{5 6}$ 908-914

Houben H, Vandenbroucke AT, Verheyden AM \& Denef C 1993 Expression of the genes encoding bombesin related peptides and their receptors in anterior pituitary tissue. Molecular and Cellular Endocrinology 97 159-164.

Hunter WM \& Greenwood FC 1962 Preparation of iodine-131 labeled human growth hormone of high specific activity. Nature 194 495-496.

Jones PM, Winthers DJ, Ghatei MA \& Bloom SR 1992 Evidence for neuromedin-B synthesis in the rat anterior pituitary gland. Endocrinology 130 1829-1836.

Kim SW, Harney JW \& Larsen PR 1998 Studies of the hormonal regulation of type $2,5^{\prime}$-iodothyronine deiodinase messenger ribonucleic acid in pituitary tumor cells using semiquantitative reverse transcription-polymerase chain reaction. Endocrinology 139 4895-4905.

Lach EB, Broad S \& Rozengurt E 1995 Mitogenic signaling by transfected neuromedin B receptors in Rat-1 cells. Cell Growth and Differentiation 11 1427-1435.

Lechan RM \& Fekete C 2004 Feedback regulation of thyrotropinreleasing hormone $(\mathrm{TRH})$ : mechanisms for the non-thyroidal illness syndrome. Fournal of Endocrinological Investigation 27 105-119.

Maia AL, Kieffer JD, Harney JW \& Larsen PR 1995 Effect of 3,5, $3^{\prime}$-triiodothyronine (T3) administration on diol gene expression and T3 metabolism in normal and type 1 deiodinase-deficient mice. Endocrinology 136 4842-4849.

Minamino M, Kangawa K \& Matsuo H 1983 Neuromedin B: a novel bombesin-like peptide identified in porcine spinal cord. Biochemical and Biophysical Research Communications 114 541-548.

Moody TW, Fagarasan M \& Zia F 1995 Neuromedin B stimulates arachidonic acid release, c-fos gene expression, and the growth of C6 glioma cells. Peptides 16 1133-1140.

Ohki-Hamazaki H, Sakai Y, Kamata K, Ogura H, Okuyama S, Watase K, Yamada K \& Wada K 1999 Functional properties of two bombesin-like peptide receptors revealed by the analysis of mice lacking neuromedin B receptor. Fournal of Neuroscience $\mathbf{9}$ 948-954.

Ortiga-Carvalho TM, Polak J, McCann S \& Pazos-Moura CG 1996 Effect of thyroid hormones on pituitary neuromedin $\mathrm{B}$ and possible interaction between thyroid hormones and $\mathrm{NB}$ on thyrotropin secretion. Regulatory Peptides 67 47-53.

Ortiga-Carvalho TM, Curty FH, Nascimento-Saba CG, Moura EG, Polak J \& Pazos-Moura CG 1997 Pituitary neuromedin B content in experimental fasting and diabetes mellitus and correlation with thyrotropin secretion. Metabolism 46 149-153.

Ortiga-Carvalho TM, Oliveira KJ, Morales MM, Martins VP \& Pazos-Moura CC 2003 Thyrotropin secretagogues reduce rat pituitary neuromedin $\mathrm{B}$, a local thyrotropin release inhibitor. Experimental Biology and Medicine (Maywood, N7) 228 1083-1088.

Pazos-Moura CG, Moura EG, Rettori V, Polak J \& McCann SM 1996 Role of neuromedin B in the in vitro thyrotropin release in response to thyrotropin-releasing hormone from anterior pituitaries of eu-, hypo-, and hyperthyroid rats. Proceedings of the Society for Experimental Biology and Medicine 211 353-358.

Pazos-Moura CG, Ortiga-Carvalho TM \& Moura EG 2003 The autocrine/paracrine regulation of thyrotropin secretion. Thyroid $\mathbf{1 3}$ $167-175$. 
Persani L 1998 Hypothalamic thyrotropin-releasing hormone and thyrotropin biological activity. Thyroid 8 941-946.

Pontiroli AE \& Scarpignato C 1986 Effect of bombesin on basal and stimulated secretion of some pituitary hormones in humans. Hormone Research 23 129-135.

Rettori V, Milenkovic L, Fahim AM, Polak J, Bloom SR \& McCann SM 1989 Role of neuromedin B in the control of the release of thyrotropin in the rat. PNAS 86 4789-4792.

Rettori V, Pazos-Moura CC, Moura EG, Polak J \& McCann SM 1992 Role of neuromedin B in the control of the release of thyrotropin in hypothyroid and hyperthyroid rats. PNAS $\mathbf{8 9}$ 3035-3039.

Schomburg L \& Bauer K 1995 Thyroid hormones rapidly and stringently regulate the messenger RNA levels of the thyrotropin-releasing hormone (TRH) receptor and the TRH-degrading ectoenzyme. Endocrinology 136 3480-3485.

Steel JH, Van Noorden S, Ballesta J, Gibson SJ, Ghatei MA, Burrin J, Leonhardt U, Domin J, Bloom SR \& Polak JM 1988 Localization of 7B2, neuromedin B, neuromedin $\mathrm{U}$ in specific cell types of rat, mouse and human pituitary, in rat hypothalamus, and in 30 human pituitary and extrapituitary tumors. Endocrinology 122 270-282.

Tajima K, Namba M, Oda Y, Matsui I, Mori M, Kitajima K, Mashita K \& Tarui S 1989 Inhibitory effect of neuromedin B on the release of thyrotropin from perfused rat pituitaries. Biomedical Research $10443-446$.

Von Schrenck TV, Heinz-Erian P, Moran T, Mantey AS, Gardner JD \& Jensen RT 1989 Neuromedin B receptor in esophagus: evidence for subtypes of bombesin receptors. American Fournal of Physiology 256 G747-G758.

Wada E, Way J, Shapira H, Kusano K, Lebecq-Verheyden AM, Coy D, Jensen RT \& Battey JF 1991 cDNA cloning, characterization, and brain region-specific expression of a neuromedin B-preferring bombesin receptor. Neuron 6 421-430.
Wada E, Wray S, Key S \& Battey JF 1992 Comparison of gene expression for two distinct bombesin receptor subtypes in postnatal rat central nervous system. Molecular and Cellular Neurosciences 3 446-460.

Wang LH, Battey JF, Wada E, Lin JT, Mantey S, Coy DH \& Jensen RT 1992 Activation of neuromedin B-preferring bombesin receptors on rat glioblastoma C-6 cells increases cellular $\mathrm{Ca}^{2+}$ and phosphoinositides. Biochemical fournal 286 641-648.

Weber HC, Hampton LL, Jensen RT \& Battey JF 1998 Structure and chromosomal localization of the mouse bombesin receptor subtype 3 gene. Gene 211 125-131.

Yamada M, Saga Y, Shibusawa N, Hirato J, Murakami M, Iwasaki T, Hashimoto K, Satoh T, Wakabayashi K, Taketo MM et al. 1997 Tertiary hypothyroidism and hyperglycemia in mice with targeted disruption of the thyrotropin-releasing hormone gene. PNAS $9410862-10867$.

Yamada K, Wada E, Yamano M, Sun YJ, Ohara-Imaizumi M, Nagamatsu S \& Wada K 2002a Decreased marble burying behavior in female mice lacking neuromedin B receptor (NMB-R) implies the involvement of NMB/NMB-R in 5-HT neuron function. Brain Research 942 71-78.

Yamada K, Santo-Yamada Y \& Wada K $2002 b$ Restraint stress impaired maternal behavior in female mice lacking the neuromedin B receptor (NMB-R) gene. Neuroscience Letters 330 163-166.

Yamada K, Santo-Yamada Y \& Wada K 2003 Stress-induced impairment of inhibitory avoidance learning in female neuromedin B receptor-deficient mice. Physiology and Behavior 78 303-309.

Received 16 September 2005

Accepted 28 October 2005 